\title{
CONTROLLING INVASIVE EXOTICS: A TALLOW TREE REPLACEMENT PROGRAM CAMPAIGN IN FLORIDA
}

\section{by Francis E. Putz, ${ }^{1}$ Mary Holdnak, ${ }^{1}$ and Meg Niederhofer ${ }^{2}$}

\begin{abstract}
The experiences of a community group in Florida that sponsored a campaign to curb local expansion of Sapium sebiferum (tallow tree), an invasive exotic tree, may be useful for other exotic species control programs. Success of the tallow replacement program was due, in part, to a partnership formed with the nursery industry. Convincing the public that not all trees are environmentally beneficial and enlisting public participation in the campaign were major challenges. Assistance came in the unexpected form of several vitriolic letters to the editor of the local newspaper in which the sponsors of the program were condemned for believing that they had the right to determine the fate of a tree, even an invasive exotic. The published exchange of letters was beneficial insofar as it kept the issue of exotics prominently in the public eye.
\end{abstract}

Key Words. Exotic species; invasive species; environmental education.

A substantial proportion of the recent ecosystem degradation suffered by our planet has resulted from intercontinental transportation and introduction of species that subsequently invade and transform indigenous ecosystems (Simberloff 1997). While the costs of maintaining natural ecosystems by controlling invasive species in parks and other nature preserves are skyrocketing, public awareness of the problem is lagging. Particularly difficult to communicate is the idea that not all trees and not all types of diversity are necessarily good. A reasonable step towards reducing the environmental threats posed by a known invasive species is to encourage public participation in its removal. In recognition of the need for public approval and participation in exotic species control, an anti-tallow tree (Sapium sebiferum) campaign was initiated in Gainesville, Florida. With the goal of increasing the effectiveness of other efforts at curbing the onslaught of invasive exotic species, this article outlines our strategies, reports on our successes, and elaborates on our tactical errors.

\section{HORTICULTURAL AND ECOLOGICAL FEATURES OF TALLOW TREES}

Garnering public support for an anti-tallow tree campaign was challenging because, in many ways, the species is horticulturally superb. This wellknown species that originated in Asia grows rapidly under a variety of conditions (Jones and McLeod 1990), suffers little from pests or pathogens, requires little tending, produces attractive white fruits, and has foliage that turns bright orange in the autumn (Randall and Marinelli 1996). Unfortunately, tallow fruits are also attractive to birds and other wildlife that readily disperse the seeds. Given that a 3-yearold tree with a stem caliper of only $10 \mathrm{~cm}$ (3.9 in.) might already be producing 100,000 seeds per year (G. Jubinsky, personal communication), a high proportion of which are viable, the potential rate of tallow invasion is alarming. Tallow seeds also seem to be water dispersed, and the seedlings tolerate flooding to the same degree as red maple (Acer rubrum) and bald cypress (Taxodium distichum) (Jones and Sharitz 1990). Perhaps not surprisingly, it is in wetland communities that tallow trees seem to be having their most severe impacts.

Tallow trees are invading natural and semi-natural communities all over the southeastern United States. Many floodplain forests along the coastal plain now have understories dominated by tallow. In Texas, coastal prairies have been transformed into tallow forests (Bruce et al. 1995).

Land stewards and other environmentalists are aware of the problem posed by the tallow tree (Randall and Marinelli 1996), and legislation prohibiting its commercial propagation or sale has passed or is pending in Florida and several other states. Although Florida's Exotic Plant Pest Council (1995) lists it as a Category I Species (i.e., a species that is invading and disrupting native plant communities), Florida Trend Magazine recently ran a full-color story 
on tallow in which its many horticultural virtues were extolled. The gardening sections of newspapers in the region also regularly promote tallow trees. $\mathrm{Ob}$ viously, the battle against tallow is and will continue to be uphill.

\section{ENVIRONMENTAL EDUCATION ABOUT INVASIVE EXOTIC SPECIES}

To increase the likelihood that people in Gainesville, Florida, will realize that their horticultural decisions can have adverse effects on local parks and other nature preserves, we carried out a multifaceted environmental education campaign aimed at tallow eradication. First, the City of Gainesville arborist, together with the city's Tree Advisory Board and the Department of Botany at the University of Florida, solicited support for the campaign from the Florida Native Plant Society, Kanapaha Botanical Garden, the City Beautification Board, various local garden clubs, and other county and state governmental agencies such as the Florida Department of Agriculture's Division of Plant Industry, the state Division of Forestry, Alachua County's Environmental Protection Department, and the Florida Department of Environmental Protection. Managers at Paynes Prairie State Preserve, a bit of natural Florida that is much beleaguered by tallow and other exotics, also endorsed the program. With the support of these organizations, we asked local members of the Florida Nursery Growers Association to offer discounts on trees of native species purchased as replacements for tallow trees removed from private property. Several nurseries agreed and advertised 30\% discounts on desirable replacement trees. Supporting organizations were acknowledged individually on Arbor Day posters printed for the campaign (Figure 1). These 4-color posters were designed in such a way that they can be used in future years as well. The city arborist and the Tree Advisory Board also prepared a brochure about tallow trees to be distributed to tallow owners by the regional electric utility's line clearance coordinators during their annual visits to homes with overhead utility wires. With a broad base of support in the community, we scheduled a series of events related to the Gainesville Arbor Week celebration.

In keeping with a local tradition, city staff together with volunteers from the University of Florida,
Florida Cooperative Extension, and the Gainesville Garden Club held a series of tree planting ceremonies at local elementary schools. The volunteers helped the students at 11 schools plant trees and talked about the importance of trees. We planned to talk about the problem with tallow trees, but the students' abundant enthusiasm (most were third-graders) and lack of time often made it difficult to introduce the concept that not all trees are beneficial.

During our Arbor Day ceremonies, in addition to acknowledging Gainesville as a Tree City U.S.A. (for the 13th year in a row) and applauding the "Treemendous" Gainesville Program (more than 1,000 trees planted per year on city lands and rightsof-way), Greg Jubinsky from the Exotic Plant Pest Council and Jim Weimer from Paynes Prairie State Preserve gave public lectures about the regional and local threat posed by tallow trees. The lectures were

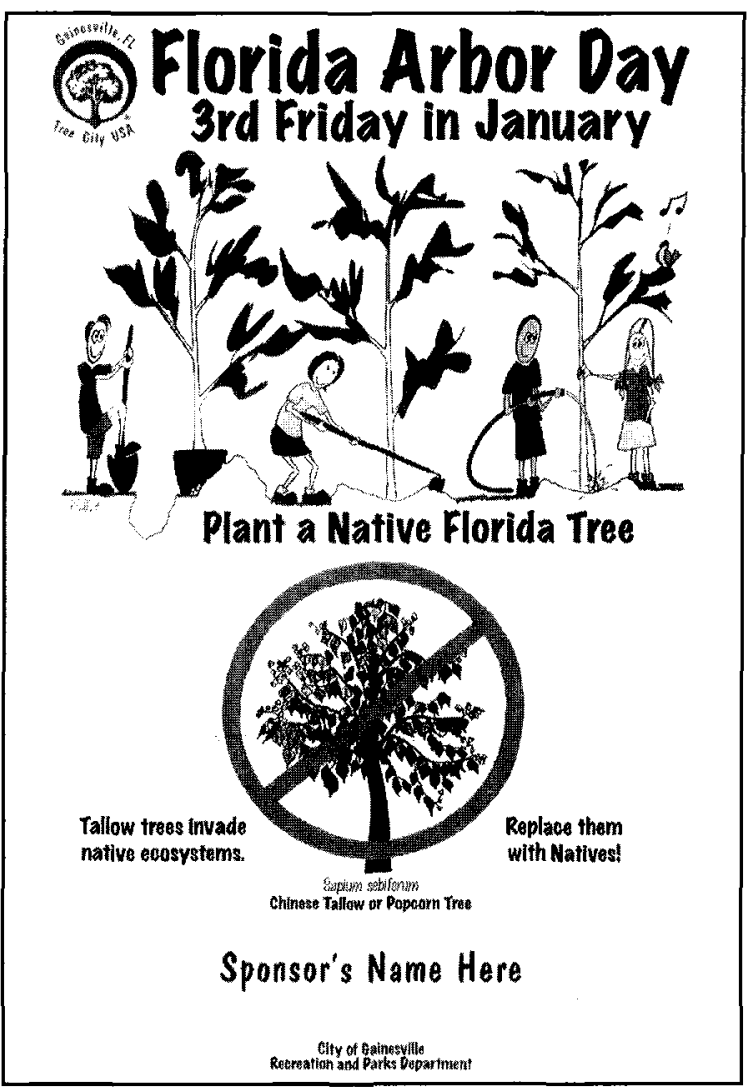

Figure 1. A black-and-white rendition of a color poster used on Arbor Days for the tallow tree replacement program. 
well attended (approximately 100 people) and received some media coverage.

We held 3 other media events that highlighted the tallow problem and the tree replacement solution. Prior to these events, we kept the environmental reporters at local newspapers informed about the programs. The results were 2 articles with pictures in The Gainesville Sun (circulation 59,000 daily), and several related stories in other newspapers and on local radio and television stations. The Sun published stories on the removal of tallows from Kanapaha Botanical Garden and on a Tree Advisory Board member cutting down a large tallow along a main thoroughfare. Unfortunately, by the third scheduled event (the allimportant replanting of a live oak by the City Beautification Board), the news media were apparently saturated with tallow-related stories. Nonetheless, our goal of informing the public about the campaign was achieved at almost no cost.

The tallow tree replacement campaign evoked considerable public response, not all supportive. Two letters to the editor of The Gainesville Sun, in particular, were scathing in their denunciation of the campaign, the city arborist, the Tree Advisory Board, and tree cutters in general. Published responses to these criticisms were numerous and very supportive but, more important, this heated public exchange seemed very effective at increasing awareness of the issue of invasive exotics. Months after commencement of the campaign, the University of Florida's delays in complying with repeated requests to remove its tallow trees also received press coverage.

\section{LESSON LEARNED AND RECOMMENDATIONS}

Although we were generally pleased with the outcome of the tallow tree replacement campaign, we learned some lessons that should help us in the future and may help other groups contemplating similar programs. First and foremost, environmental managers need to work harder at communicating to the public the concept of ecosystem management. The public needs to understand that maintenance of healthy natural ecosystems needs to begin in their own backyards. It is also critical that the public recognizes that maintaining natural ecosystems often requires active management. Where the seedsheds of nature preserves include suburban areas, problems with invasive, exotic, horticultural species are often severe. Management of these natural areas cannot stop at preserve boundaries but should encompass the surrounding areas. And finally, these messages need to be widely and clearly proclaimed.

The backlash against removing tallow trees might have been avoided if we had planted a native tree immediately in the place of the tallow tree we cut down. This arrangement was not possible at the site selected because there was only one appropriate planting spot and it was occupied by the herbicidetreated tallow stump. In retrospect, we should have selected a different site where tallow tree removal and replacement could have been more closely juxtaposed in time. Designers of tree replacement programs might generally be more careful about proceeding gently, lest the critical support of tree lovers is lost.

The message that not all trees are necessarily good is difficult to communicate. Because of this contradistinction, Arbor Day may not have been the best choice of times to start an exotic tree eradication campaign; perhaps Earth Day might have been more appropriate. Above all, we need to build awareness of the invasive exotic problem while simultaneously fostering support for the urban forest.

\section{LITERATURE CITED}

Bruce, K.A., G.N. Cameron, and P.A. Harcombe 1995. Initiation of a new woodland type on the Texas coastal prairie by the Chinese tallow tree (Sapium sebiferum (L.) Roxb.). Bull. Torrey Bot. Club 122:215-225.

Jones, R.H., and K.W. McLeod. 1990 Growth and photosynthetic responses to a range of environments in Chinese tallowtree and Carolina ash seedlings. For. Sci. 36:851-862.

Jones, R.H., and R.R. Sharitz. 1990. Effects of root competition and flooding on growth of Chinese tallow seedlings. Can. J. For. Res. 20:573-578.

Randall, J.M., and T. Marinelli (Eds.). 1996. Invasive Plants. Weeds of the Global Garden. Brooklyn Botanical Garden, New York, NY.

Simberloff, D. 1997. Strangers in Paradise: Impact and Management of Nonindigenous Species in Florida. Island Press, Washington, DC. 
${ }^{1 *}$ Department of Botany

University of Florida

Gainesville, FL 32611

${ }^{2}$ Parks Division

City of Gainesville

P.O. Box 420, Sta. 27

Gainesville, FL 32602

\section{${ }^{*}$ Corresponding author: Francis Putz}

Résumé. Les expériences d'un groupe communautaire de Floride qui a commandité une campagne pour freiner l'expansion de Sapium sebiferum (gluttier à suif), une espèce exotique échappée de culture, pourrait être utile à d'autres programmes de contrôle d'espèces exotiques. Convaincre le public que tous les arbres ne sont pas nécessairement désirables du point de vue de l'environnement et gagner leur appui dans cette campagne étaient des défis majeurs. L'assistance est venue d'une façon inattendue par plusieurs lettres à l'éditeur du journal local dans lesquelles les commanditaires du programme ont été condamnés avec tous les autres pour avoir l'impudence de croire qu'ils ont le droit de déterminer le destin d'un arbre. La publication de ces échanges de lettres a été bénéfique parce qu'elle a permis de mettre ce sujet à l'avantplan dans les yeux du publics.

Zusammenfassung. Die Erfahrungen einer Gruppe von Gemeinden in Florida, die ein Programm zur Bekämpfung der lokalen Verbreitung von Sapium sebiferum, einer evasiven exotischen Baumart, könnten bei Entwicklung von Kontrollprogrammen für andere exotische Pflanznearten nützlich sein. Die Hauptaufgaben des Programms bestand darin, die Öffentlichkeit zu überzeugen, daß nicht alle Bäume an ihrem Standort okologisch sinnvoll und das eine Mitarbeit in dem Programm erwünscht wird. Unterstützung erfuhr das Projekt von ganz unerwarteter Seite durch eine Reihe von Schmähbriefen an den Herausgeber der lokalen Zeitung, in welchen die Sponsoren des Programms zusammen mit allen andern, die sich erdreisten würden zu glauben, sie hätten das Recht, über die Ausrottung einer Pflanzenart zu bestimmen, vom Verfasser verdammt wurden. Die Veroffentlichung des Briefwechsels war insofern von Vorteil, als daß das Thema ständig im Augenblick der Öffentlichkeit stand.

Resumen. Las experiencias de un grupo de comunidades en Florida que patrocinó una campaña para restringir la expansión local de Sapium sebiferum (Sebo chino), un árbol exóticu evasivo, puede ser útil para otros programas de control de especies exóticas. El convencimiento del público de que no todos los árboles son ambientalmente deseables y conseguir su participación en la campaña fueron sus principales desafíos. La ayuda llegó inesperadamente en forma de varias cartas al editor de un periódico local, en las cuales los patrocinadores del programa fueron condenados, junto con cualquier otro lo suficientemente cínico como para creerse con derecho a determinar el destino de un árbol. El intercambio publicado de cartas fue beneficioso porque mantuvo el tema bajo la atención del público. 